\title{
Editorial \\ Immunotherapy in Myeloma: A Theme Issue in Honor of Prof. Dr. Gösta Gahrton
}

\author{
Nicolaus Kröger ${ }^{1, *}$ and Laurent Garderet ${ }^{2}$ (D) \\ 1 Department of Stem Cell Transplantation, University Medical Center Hamburg-Eppendorf, \\ 20246 Hamburg, Germany \\ 2 Service d'Hématologie, Hôpital Pitié Salpêtrière, 47-83 Boulevard de L'hôpital, F-75013 Paris, France; \\ laurent.garderet@aphp.fr \\ * Correspondence: nkroeger@uke.uni-hamburg.de
}

Citation: Kröger, N.; Garderet, L. Immunotherapy in Myeloma: A

Theme Issue in Honor of Prof. Dr. Gösta Gahrton. Hemato 2022, 3, 1-2. https://doi.org/10.3390/ hemato3010001

Received: 13 December 2021 Accepted: 13 December 2021 Published: 22 December 2021

Publisher's Note: MDPI stays neutral with regard to jurisdictional claims in published maps and institutional affiliations.

Copyright: (C) 2021 by the authors Licensee MDPI, Basel, Switzerland. This article is an open access article distributed under the terms and conditions of the Creative Commons Attribution (CC BY) license (https:// creativecommons.org/licenses/by/ $4.0 /)$.
Immunotherapy has become a major pillar in the treatment of multiple myeloma. This Special Issue of Hemato addresses the increasing role of immunotherapy-based treatment options in multiple myeloma and is dedicated to Prof. Gösta Gahrton, former president of the European Society for Blood and Marrow Transplantation (EBMT), who, in 1987, published results of allogeneic stem cell transplantation as one of the most effective immunotherapies in patients with multiple myeloma [1]. Even if allogeneic stem cell transplantation has not found its definitive role in the treatment of multiple myeloma, our understanding of the immunological interaction of myeloma cells and the microenvironment and the improving techniques of monoclonal or bispecific antibodies and CAR-T technology as well as translational research on myeloma has rapidly developed in the last 30 years and immunotherapy has become a major backbone in the treatment of multiple myeloma.

After a personal introduction to Prof. Gahrton by Per Ljungman, Juan Luis RegueraOrtega from José A. Pérez-Simón's group in Sevilla presents an overview of the rapidly growing field of chimeric antigen receptor T-cells (CAR-T) in myeloma [2], before Nico Gagelmann, from the Hamburg group, summarizes the effect of donor T-cells (DLI) after allogeneic stem cell transplantation to enhance the graft-versus-myeloma effect [3]. The increasing role of natural killer cells is highlighted and reviewed by Marie Therese Rubio, Adèle Dhuyser, and Stéphanie Nguyen from Nancy [4].

The development of monoclonal, bispecific, and immune conjugated antibodies is described by Christie Verkleij, Wassilis Bruins, Sonja Zweegman, and Niels van de Donk from Amsterdam [5], while Benedetto Bruno together with Giuseppe Lia, Francesca Bonifazi, and Luisa Giaccone describe the development and progress in allogeneic stem cell transplantation for myeloma in the last decades [6]. This Special Issue closes with an article by Luis Gerardo Rodríguez-Lobato from Joan Bladé's group in Barcelona summarizing the current knowledge about the failure of immunotherapy in multiple myeloma [7].

All the contributions are excellent state-of-the-art studies and the editors express their deep gratitude to the authors and hope that readers will enjoy this Special Issue on this exciting field in the treatment of multiple myeloma.

Funding: This research received no external funding.

Conflicts of Interest: The authors declare no conflict of interest. 


\section{References}

1. Gahrton, G.; Tura, S.; Flesch, M.; Gratwohl, A.; Gravett, P.; Lucarelli, G.; Michallet, M.; Reiffers, J.; Ringdén, O.; van Lint, M.T.; et al. Transplantation in Multiple Myeloma: Report from the European Cooperative Group for Bone Marrow Transplantation. Blood 1987, 4, 1262-1264. [CrossRef]

2. Reguera-Ortega, J.L.; García-Guerrero, E.; Pérez-Simón, J.A. Current Status of CAR-T Cell Therapy in Multiple Myeloma. Hemato 2021, 2, 660-671. [CrossRef]

3. Gagelmann, N.; Kröger, N. Donor Lymphocyte Infusion to Enhance the Graft-versus-Myeloma Effect. Hemato $2021,2,207-216$. [CrossRef]

4. Rubio, M.T.; Dhuyser, A.; Nguyen, S. Role and Modulation of NK Cells in Multiple Myeloma. Hemato 2021, 2, 167-181. [CrossRef]

5. Verkleij, C.P.M.; Bruins, W.S.C.; Zweegman, S.; van de Donk, N.W.C.J. Immunotherapy with Antibodies in Multiple Myeloma: Monoclonals, Bispecifics, and Immunoconjugates. Hemato 2021, 2, 116-130. [CrossRef]

6. Bruno, B.; Lia, G.; Bonifazi, F.; Giaccone, L. Decades of Progress in Allogeneic Stem Cell Transplantation for Multiple Myeloma. Hemato 2021, 2, 89-102. [CrossRef]

7. Rodríguez-Lobato, L.G.; Oliver-Caldés, A.; Moreno, D.F.; Fernández de Larrea, C.; Bladé, J. Why Immunotherapy Fails in Multiple Myeloma. Hemato 2021, 2, 1-42. [CrossRef] 